\title{
Effect of intravenous corticosteroid on ex vivo leukotriene generation by blood leucocytes of normal and asthmatic patients
}

\author{
Pauline P Hood, Timothy P Cotter, John F Costello, Anthony P Sampson
}

\begin{abstract}
Background-The cysteinyl-leukotrienes $\left(\mathbf{L T C}_{4}, \mathbf{L T D}_{4}, \mathrm{LTE}_{4}\right)$ are critical bronchoconstrictor and eosinophilotactic mediators in asthma while $\mathbf{L T B}_{4}$ is a potent neutrophil chemoattractant. Glucocorticosteroids are front line antiinflammatory treatment for asthma but the evidence that they reduce leukotriene (LT) synthesis in vivo is poor.
\end{abstract}

Methods-In a randomised, double blind, placebo controlled, crossover trial immunoassays were used to measure ex vivo synthesis of $\mathrm{LTC}_{4}$ and $\mathrm{LTB}_{4}$ by calcium ionophore stimulated blood leucocytes and bronchoalveolar lavage (BAL) cells of eight normal subjects and eight patients with mild allergic asthma 4-6 hours after intravenous administration of a single $100 \mathrm{mg}$ dose of methylprednisolone.

Results-Ionophore stimulated synthesis of $\mathrm{LTC}_{4}$ (but not $\mathrm{LTB}_{4}$ ) in blood granulocytes tended to be higher in asthmatic subjects (mean $9.7 \mathrm{ng} / 10^{6}$ cells) than in normal subjects $\left(4.2 \mathrm{ng} / 10^{6}\right.$ cells; $\left.\mathrm{p}=0.08\right)$ and intravenous methylprednisolone reduced synthesis of LTC $_{4}$ (but not LTB $_{4}$ ) to normal levels $\left(2.9 \mathrm{ng} / 10^{6}\right.$ cells; $95 \%$ CI for the reduction 1.0 to $12.5 \mathrm{ng} / 10^{6}$ cells; $\mathrm{p}=$ 0.03). In blood mononuclear cells methylprednisolone reduced LTC $_{4}$ synthesis in asthmatic subjects from 1.26 to $0.79 \mathrm{ng} / 10^{6}$ cells $(95 \%$ CI for the reduction 0.26 to 0.79 , $\mathbf{p}=0.014)$ and tended to reduce $\mathrm{LTC}_{4}$ synthesis in normal subjects from 1.51 to $0.86 \mathrm{ng} / 10^{6}$ cells $(\mathrm{p}=0.08)$. Methylprednisolone also significantly reduced synthesis of $\mathrm{LTB}_{4}$ in mononuclear cells from both subject groups $(p=0.014)$. It had no effect on LT synthesis in BAL cells from either group nor on LT levels in BAL fluid.

Conclusions-Intravenous methylprednisolone can reduce synthesis of leukotrienes in blood granulocytes and mononuclear cells within six hours of a single intravenous dose.

(Thorax 1999;54:1075-1082)

Keywords: leukotrienes; corticosteroids; asthma

Leukotrienes (LT) are products of arachidonic acid synthesised by the 5-lipoxygenase (5-LO) pathway. The cysteinyl-LTs $\left(\mathrm{LTC}_{4}, \mathrm{LTD}_{4}\right.$, and $\mathrm{LTE}_{4}$ ) are potent constrictors of human bronchial smooth muscle and cause mucus hypersecretion and airway oedema. ${ }^{1}$ Cysteinyl-LTs are also potent and specific chemoattractants for human eosinophils in vivo. ${ }^{2}$ Concentrations of cysteinyl-LTs in the bronchoalveolar lavage (BAL) fluid and urine of asthmatic subjects rise after allergen challenge and during acute asthma exacerbations. ${ }^{34}$ Clinical trials of specific anti-leukotriene drugs have confirmed the major contribution of cysteinyl-LTs to bronchoconstriction and eosinophilia in asthma. ${ }^{56} \mathrm{LTB}_{4}$ is a potent leucocyte chemotaxin in vivo ${ }^{7}$ but there is relatively little evidence for a role in asthma. ${ }^{8}$

Glucocorticosteroids are a mainstay of asthma treatment due to their modulation of the expression of pro-inflammatory cytokines and adhesion molecules. They reduce the synthesis of leukotrienes in vitro by upregulating the expression of lipocortin which inhibits liberation of arachidonic acid from membrane phospholipids by phospholipase $\mathrm{A}_{2} .{ }^{9}$ However, it is not clear whether corticosteroids suppress LT synthesis in vivo. Treatment of normal and asthmatic subjects with oral or inhaled corticosteroids for up to 14 days did not reduce urinary excretion of $\mathrm{LTE}_{4}$ or BAL fluid levels of $\mathrm{LTB}_{4} \cdot{ }^{10-13}$ However, in normal and asthmatic subjects treatment with oral prednisone for seven days significantly suppressed reduced ex vivo release of $\mathrm{LTB}_{4}$ by BAL cells. ${ }^{10}{ }^{13}$ Long term oral corticosteroid treatment of asthmatic subjects may also abolish ex vivo synthesis of $\mathrm{LTB}_{4}$ in ionophore stimulated blood granulocytes and mononuclear cells. ${ }^{14}$

The clinical benefits of systemic corticosteroids on admission rate and peak expiratory flow in acute severe asthma begin to be observed at about four hours. ${ }^{15}{ }^{16}$ Suppression of $\mathrm{LTB}_{4}$ synthesis in alveolar macrophages is apparent within 13 hours of treatment with oral prednisone in subjects with nocturnal asthma. ${ }^{17}$ No previous studies have investigated ex vivo LT synthesis within 12 hours of a single dose of systemic corticosteroid, or at any time after intravenous administration. Furthermore, most studies have focused on ex vivo $\mathrm{LTB}_{4}$ synthesis whereas the role of cysteinyl-LTs in asthma is much better established. We hypothesised that systemic corticosteroids may suppress $\mathrm{LTB}_{4}$ and/or $\mathrm{LTC}_{4}$ synthesis in blood and/or airway leucocytes within 4-6 hours. A double blind, placebo controlled, randomised, crossover trial of the effects of an intravenous bolus dose of $100 \mathrm{mg}$ methylprednisolone on ex vivo synthesis of LTs in BAL cells and in blood granulocytes and mononuclear cells and on BAL fluid LT levels was therefore carried out in eight mild allergic asthmatic patients and eight normal subjects. 


\section{Methods}

PATIENT RECRUITMENT

Permission for the study was obtained from King's College Hospital ethics committee and all subjects gave informed written consent to take part. All subjects were non-smokers. Eight patients with mild atopic asthma and eight non-atopic normal subjects were recruited. Asthmatic patients (4M, 4F; median age 25 years, range 23-30) had positive skin prick tests (weal $>2 \mathrm{~mm}$ ) to at least two common allergens and geometric mean serum $\operatorname{IgE}$ of $245 \mathrm{IU} / \mathrm{ml}$ (range 135-446). Asthmatic patients had an appropriate clinical history and bronchial hyperreactivity to inhaled methacholine $\left(\mathrm{PC}_{20}<8 \mathrm{mg} / \mathrm{ml}\right)$ but were stable at the time of study with a median forced expiratory volume in one second $\left(\mathrm{FEV}_{1}\right)$ of $97 \%$ (range 83-122). Asthmatic patients used inhaled $\beta_{2}$ agonist bronchodilators but had not used theophylline, cromones, or oral or inhaled corticosteroids for at least six weeks before the study. Normal subjects (3M, 5F; median age 22.5 years, range 20-30) had no history of chronic respiratory disease, provided normal lung function tests (median $\mathrm{FEV}_{1}$ 94\%, range 86-106) with methacholine $\mathrm{PC}_{20}>16 \mathrm{mg} / \mathrm{ml}$, and had negative skin prick tests with total serum IgE of $9 \mathrm{IU} / \mathrm{ml}$ (range $4-25 ; \mathrm{p}<0.001$ versus asthmatic patients).

BRONCHOSCOPY AND BRONCHOALVEOLAR LAVAGE In a double blind, randomised, crossover manner, normal and asthmatic subjects received an intravenous bolus dose of $144 \mathrm{mg}$ methylprednisolone suleptanate (Upjohn; $100 \mathrm{mg}$ methylprednisolone equivalents) and a placebo (sterile $0.9 \%$ saline solution) at least two weeks apart. Four hours after each intravenous dose $100 \mathrm{ml}$ of peripheral venous blood was taken for differential cell counting by a blinded observer and for leucocyte isolation. Subjects immediately underwent bronchoscopy using an Olympus BF P20D flexible fibreoptic bronchoscope as described. ${ }^{18}$ Bronchoalveolar lavage was performed with three $60 \mathrm{ml}$ aliquots of warmed sterile saline $\left(0.9 \% ; 37^{\circ} \mathrm{C}\right)$ containing inulin $(0.1 \mathrm{mM})$ and BAL fluid was separated from cells by centrifugation. The supernatant was concentrated 10-fold by evaporation and stored at $-70^{\circ} \mathrm{C}$. Yields of BAL cells were typically $7-14$ million with mean viability of $96 \%$ (always $>86 \%$ ) assessed by exclusion of Trypan blue dye $0.01 \%$ (Sigma). Differential cell counts were performed by morphology after staining with Diff-Quik (Baxter Healthcare, Thetford, UK).

ISOLATION OF BLOOD POLYMORPHONUCLEAR LEUCOCYTES AND MONONUCLEAR CELLS

Venous blood anticoagulated with sodium heparin $(10-20 \mathrm{IU} / \mathrm{ml})$ was layered onto Ficoll-Paque $(1.077 \mathrm{~g} / \mathrm{ml}$; Pharmacia LKB, Uppsala, Sweden) and centrifuged at $400 \mathrm{~g}$ for 30 minutes. The mononuclear cell (MNC) layer was aspirated, resuspended in $\mathrm{Ca}^{2+} / \mathrm{Mg}^{2+}$ free culture medium and washed by low speed centrifugation to deplete contaminating platelets. The polymorphonuclear leucocyte (PMNL) fraction was sedimented in $1.2 \%$ dextran (150-200 kD; Merck, Lutterworth, UK) for 30-45 minutes followed by ammonium chloride $(0.87 \%)$ lysis to deplete erythrocytes. Both PMNL and MNC populations were viable $(>98 \%)$ by Trypan blue exclusion. Differential counts were performed by morphology after Diff-Quik staining. PMNL were always $>90 \%$ neutrophils and $<1 \%$ mononuclear cells, with the remainder eosinophils. MNC preparations were always $>99 \%$ pure.

ASSAY OF EX VIVO LEUKOTRIENE SYNTHESIS BY BAL CELLS AND BLOOD LEUCOCYTES

Ionophore stimulated synthesis of $\mathrm{LTB}_{4}$ and $\mathrm{LTC}_{4}$ was assayed essentially as described previously. ${ }^{19}{ }^{20}$ PMNL and MNC preparations were incubated at $5 \times 10^{6}$ cells $/ \mathrm{ml}$ and BAL cells at $0.5 \times 10^{6}$ cells $/ \mathrm{ml}$ in $\mathrm{Ca}^{2+} / \mathrm{Mg}^{2+}$ containing culture medium at $37^{\circ} \mathrm{C}$ with $25 \mathrm{mM}$ HEPES and $20 \mathrm{mM}$ L-serine (Sigma) to prevent peroxidase dependent catabolism of leukotrienes. Cells were stimulated with calcium ionophore A23187 (Sigma) in dimethylsulfoxide $(<0.5 \% \mathrm{v} / \mathrm{v})$ at a final concentration of $2 \mu \mathrm{M}$ for PMNL and MNC experiments and $4 \mu \mathrm{M}$ for BAL cells. After 0 minutes (baseline) and 20 minutes reactions were terminated with ice cold methanol and leukotrienes were measured in the supernatants following evaporation and resuspension in radioimmunoassay buffer.

Radioimmunoassays for $\mathrm{LTB}_{4}$ and $\mathrm{LTC}_{4}$ were performed as described previously ${ }^{19}$ using tritiated ${ }^{3} \mathrm{H}-\mathrm{LTB}_{4}$ and ${ }^{3} \mathrm{H}-\mathrm{LTC}_{4}$ (NEN DuPont, Hounslow, UK) and standard $\mathrm{LTB}_{4}$ and $\mathrm{LTC}_{4}$ (Cascade Chemicals, Reading, UK). The rabbit polyclonal antibody for cysteinylLTs was a gift from Professor B Peskar (University of Graz, Austria) and the $\mathrm{LTB}_{4}$ antiserum was a gift from Dr A W FordHutchinson (Merck-Frosst Canada).

\section{ASSAY OF METHYLPREDNISOLONE IN BAL FLUID} AND PLASMA

Concentrations of methylprednisolone in plasma were measured by UV absorption at $254 \mathrm{~nm}$ after dichloromethane extraction and straight phase HPLC using a dichloromethane/ heptane/acetic acid/ethanol solvent mixture (600:350:10:35; $2 \mathrm{ml} / \mathrm{min})$ on a Zorbax silica column $(250 \times 4.6 \mathrm{~mm})$. Methylprednisolone in BAL fluid was purified by HPLC on a Hypersil BDS $3 \mu \mathrm{M}$ C8 column $(5 \mathrm{~cm})$ in acetonitrile/N-methylmorpholine (35:65; $1 \mathrm{ml} /$ min) and quantified by mass spectrometry (Perkin-Elmer Sciex API III).

\section{STATISTICAL ANALYSIS}

Comparisons between placebo and methylprednisolone treatments were performed by paired tests for non-parametric data (Wilcoxon sign rank sum test) and between subject groups by unpaired tests for non-parametric data (Mann-Whitney U test). A p value of $<0.05$ was considered significant. 


\section{Results}

METHYLPREDNISOLONE LEVELS IN BAL FLUID AND PLASMA

Four hours after intravenous dosing the mean (SE) plasma concentration of methylprednisolone in asthmatic subjects (315 (35) $\mathrm{ng} /$ $\mathrm{ml}$ ) was not significantly different from that in normal subjects (333 (30) $\mathrm{ng} / \mathrm{ml})$, both values equating to approximately $0.9 \mu \mathrm{M}$. Uncorrected concentrations of methylprednisolone in BAL fluid tended to be slightly lower in asthmatic subjects $(5.0(1.0) \mathrm{ng} / \mathrm{ml})$ than in normal subjects $(7.8(1.0) \mathrm{ng} / \mathrm{ml}, \mathrm{p}=0.06)$. After correction for variable dilution by instilled lavage fluid using the inulin technique $^{18}$ methylprednisolone concentrations in the original epithelial lining fluid (ELF) were estimated as $0.14 \mu \mathrm{M}$ in asthmatic subjects and $0.22 \mu \mathrm{M}$ in normal subjects, approximately one fifth those in plasma.

EFFECT OF INTRAVENOUS METHYLPREDNISOLONE ON BAL CELL AND BLOOD LEUCOCYTE DIFFERENTIAL COUNTS

After placebo there were no significant differences in total leucocyte counts between normal subjects (mean 5.9 million cells $/ \mathrm{ml}$ ) and asthmatic patients $(6.2$ million cells $/ \mathrm{ml})$, or in the mean counts of neutrophils, monocytes, or eosinophils (table 1). In normal subjects intravenous methylprednisolone more than doubled blood counts of neutrophils $(\mathrm{p}<0.01)$ and tended to reduce the mean counts of lymphocytes and monocytes $(\mathrm{p}<0.1)$. In patients with atopic asthma methylprednisolone significantly increased neutrophil counts $(p<0.02)$ and reduced counts of lymphocytes $(\mathrm{p}<0.02)$ and monocytes $(\mathrm{p}<0.02)$. In both patient groups eosinophil counts tended to be lower after methylprednisolone but this did not reach statistical significance.

After placebo BAL cell populations were predominantly macrophages in normal subjects $(92.1 \%$ of total cells) and asthmatic patients $(86.5 \%)$, with the remainder being epithelial cells, lymphocytes, neutrophils, and eosinophils (table 2). Total and differential cell counts were not significantly different between the subject groups after placebo, and methyl-

Table 1 Peripheral blood leucocyte counts $\left(\times 10^{6} / \mathrm{ml}\right)$ in normal $(n=8)$ and allergic asthmatic $(n=8)$ subjects four hours after intravenous administration of $144 \mathrm{mg}$ methylprednisolone suleptanate $(100 \mathrm{mg}$ methylprednisolone equivalents) and placebo (saline)

\begin{tabular}{lll}
\hline & Placebo & Methylprednisolone \\
\hline Normal subjects: & & \\
Total leucocytes & $5.9(5.0-8.3)$ & $8.8(5.5-12.2)$ \\
Neutrophils & $3.1(2.5-4.1)$ & $8.4(4.1-10.5)^{\star \star}$ \\
Eosinophils & $0.08(0.0-0.63)$ & $0.01(0.0-0.07)$ \\
Monocytes & $0.39(0.05-0.63)$ & $0.07(0.06-0.07)$ \\
Lymphocytes & $2.5(1.73-3.82)$ & $1.2(0.3-1.8)$ \\
Asthmatic subjects: & & \\
$\quad$ Total leucocytes & $6.2(4.2-10.3)$ & $7.9(4.9-11.3)$ \\
Neutrophils & $3.7(1.6-6.6)$ & $7.0(4.2-9.9)^{\star}$ \\
Eosinophils & $0.09(0.0-0.25)$ & $0.01(0.01-0.10)$ \\
Monocytes & $0.19(0.05-0.41)$ & $0.05(0.01-0.10)^{\star}$ \\
Lymphocytes & $2.3(1.9-2.4)$ & $0.82(0.22-1.36)^{\star}$
\end{tabular}

Values are arithmetic mean (range)

${ }^{\star} \mathrm{p}<0.02,{ }^{\star \star} \mathrm{p}<0.01$ versus placebo (Wilcoxon). There were no significant differences between the subject groups after placebo. Methyprednisolone significantly increased neutrophil counts in both subject groups and significantly reduced monocyte and lymphocyte counts in the asthmatic subjects.
Table 2 Differential bronchoalveolar lavage (BAL) cell counts (\% of total cells) in normal $(n=8)$ and allergic asthmatic $(n=8)$ subjects four hours after intravenous administration of $144 \mathrm{mg}$ methylprednisolone suleptanate (100 mg methylprednisolone equivalents) and placebo (saline)

\begin{tabular}{lcc}
\hline & Placebo & Methylprednisolone \\
\hline Normal subjects: & $92.1(87.3-94.4)$ & $92.7(79.0-98.0)$ \\
$\quad$ Macrophages & $0.5(0.2-1.1)$ & $1.1(0.1-4.2)$ \\
Neutrophils & $0.5(0.2-1.1)$ & $0.2(0.0-0.3)$ \\
Eosinophils & $3.4(0.6-6.2)$ & $2.8(0.9-6.4)$ \\
Lymphocytes & $4.1(1.3-8.1)$ & $3.2(0.7-13.2)$ \\
Epithelial cells & & \\
Asthmatic subjects: & & \\
Macrophages & $86.5(81.7-95.5)$ & $87.5(61.0-94.6)$ \\
Neutrophils & $0.7(0.0-3.3)$ & $0.6(0.1-1.4)$ \\
Eosinophils & $0.3(0.1-0.6)$ & $0.2(0.0-1.4)$ \\
Lymphocytes & $2.5(1.3-6.6)$ & $3.8(1.0-5.2)$ \\
Epithelial cells & $5.3(0.0-14.8)$ & $10.1(1.5-37)$ \\
\hline
\end{tabular}

Values are median (range). There were no significant difference between the subject groups in total or differential BAL cell counts after placebo, and methylprednisolone had no significant effect on total or differential BAL cell counts in either subject group.

prednisolone did not change the total counts of BAL cells recovered or the proportions of any BAL cell type in either subject group.

EFFECT OF INTRAVENOUS METHYLPREDNISOLONE ON LEUKOTRIENE SYNTHESIS IN BLOOD POLYMORPHONUCLEAR LEUCOCYTES

In seven normal subjects PMNL isolated from blood four hours after placebo treatment synthesised mean (SE) LTC $_{4}$ levels of 4.21 $(1.22) \mathrm{ng} / 10^{6}$ cells when stimulated with A23187 $(2 \mu \mathrm{m})$ for 20 minutes (fig 1). Intravenous methylprednisolone had no effect on ex vivo $\mathrm{LTC}_{4}$ synthesis by the PMNL of normal subjects $\left(3.89(1.76) \mathrm{ng} / 10^{6}\right.$ cells, $\mathrm{p}>0.5$ ).

In eight asthmatic patients $\mathrm{LTC}_{4}$ synthesis by PMNL after placebo (9.67 (2.62) ng/10 cells) tended to be higher than in the normal subjects (95\% confidence interval for difference -1.1 to $12.0 ; \mathrm{p}=0.08)$. $\mathrm{LTC}_{4}$ synthesis by asthmatic PMNL was significantly reduced by methylprednisolone to $2.91(0.67) \mathrm{ng} / 10^{6}$ cells $(\mathrm{p}=0.03$; fig 1$)$. The mean reduction was $6.76 \mathrm{ng} / 10^{6}$ cells (95\% CI 1.01 to 12.52 ).

$\mathrm{LTB}_{4}$ synthesis was similar in the PMNL of normal and asthmatic subjects after placebo (4.2(0.9) and $5.7(0.8) \mathrm{ng} / 10^{6}$ cells, respectively; $p>0.3)$. Methylprednisolone did not significantly alter $\mathrm{LTB}_{4}$ synthesis in PMNL from either the normal subjects $\left(6.2\right.$ (1.0) $\mathrm{ng} / 10^{6}$ cells; $\mathrm{p}>0.2)$ or the asthmatic patients $(7.2$ (1.1) $\mathrm{ng} / 10^{6}$ cells; $\mathrm{p}>0.2$ ).

EFFECT OF INTRAVENOUS METHYLPREDNISOLONE ON LEUKOTRIENE SYNTHESIS IN BLOOD MONONUCLEAR CELLS

In eight normal subjects mononuclear cells isolated from blood four hours after placebo treatment synthesised mean $\mathrm{LTC}_{4}$ levels of $1.51(0.30) \mathrm{ng} / 10^{6}$ cells when stimulated with calcium ionophore A23187 $(2 \mu \mathrm{M})$ for $20 \mathrm{~min}-$ utes (fig 2). Treatment with intravenous methylprednisolone tended to reduce ex vivo $\mathrm{LTC}_{4}$ synthesis to $0.86(0.26) \mathrm{ng} / 10^{6}$ cells but this did not reach statistical significance $(\mathrm{p}=0.07)$. The mean fall was $0.64 \mathrm{ng} / 10^{6}$ cells $(95 \% \mathrm{CI}$ -0.2 to 1.48 ). In eight asthmatic patients $\mathrm{LTC}_{4}$ 

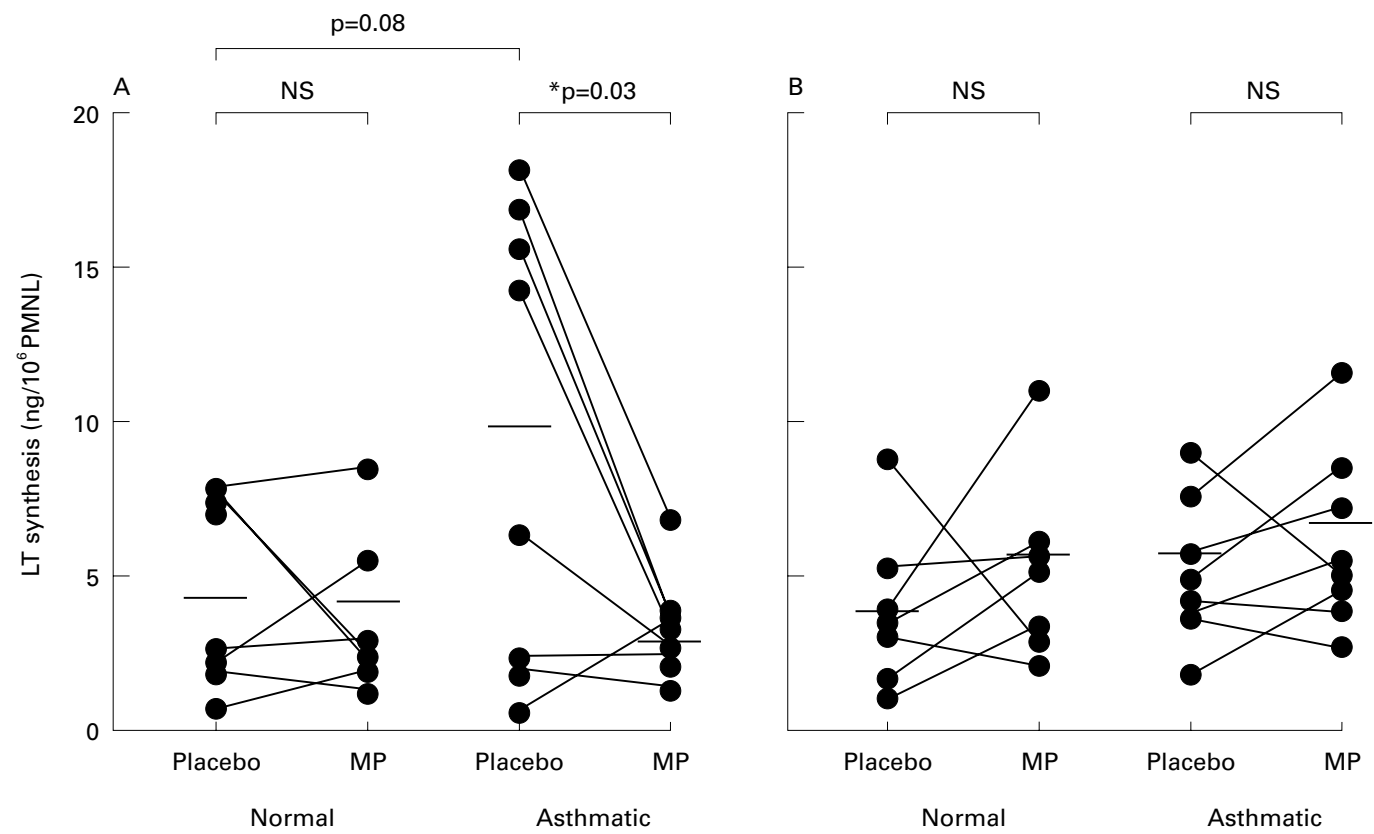

Figure 1 Ex vivo synthesis of $(A) L_{T} C_{4}$ and $(B) L_{1} B_{4}$ by $A 23187$ stimulated blood polymorphonuclear leucocytes $(P M N L)$ of normal subjects $(n=7)$ and asthmatic patients $(n=8)$ 4-6 hours after intravenous methylprednisolone (MP; $100 \mathrm{mg}$ ) and placebo. Horizontal bars indicate mean values. PMNL of asthmatic subjects tended to generate more LTC but not $L T B_{4}$, than those of normal subjects after placebo $\left(p=0.08\right.$, Mann-Whitney). MP significantly reduced LTC $C_{4}$ synthesis only in the PMNL of asthmatic patients $\left(p=0.03\right.$, Wilcoxon) and LTB ${ }_{4}$ synthesis was unaffected in both subject groups $(p>0.2)$.

synthesis by MNC after placebo was 1.26 (0.09) $\mathrm{ng} / 10^{6}$ cells, not significantly different from normal MNC, and this was significantly reduced after treatment with methylprednisolone $\left(0.79(0.12) \mathrm{ng} / 10^{6}\right.$ cells, $\mathrm{p}=0.014$ fig 2). The mean fall was $0.48 \mathrm{ng} / 10^{6}$ cells (95\% CI 0.26 to 0.79 ).

Intravenous methylprednisolone was also effective in mononuclear cells in reducing ex vivo synthesis of $\mathrm{LTB}_{4}$. In eight normal subjects
A23187 stimulated MNC generated 3.13 (0.46) $\mathrm{ng} / 10^{6}$ cells of $\mathrm{LTB}_{4}$ after placebo, which was reduced to $1.54(0.14) \mathrm{ng} / 10^{6}$ cells after methylprednisolone ( $\mathrm{p}=0.014$; fig 2 ). The mean fall was $1.59 \mathrm{ng} / 10^{6}$ cells $(95 \% \mathrm{CI}$ 0.64 to 2.54 ). In eight asthmatic patients ex vivo synthesis of $\mathrm{LTB}_{4}$ by $\mathrm{MNC}$ was 2.75 $(0.33) \mathrm{ng} / 10^{6}$ cells after placebo, not significantly different from normal MNC, and this was significantly reduced to $1.30(1.0) \mathrm{ng} / 10^{6}$
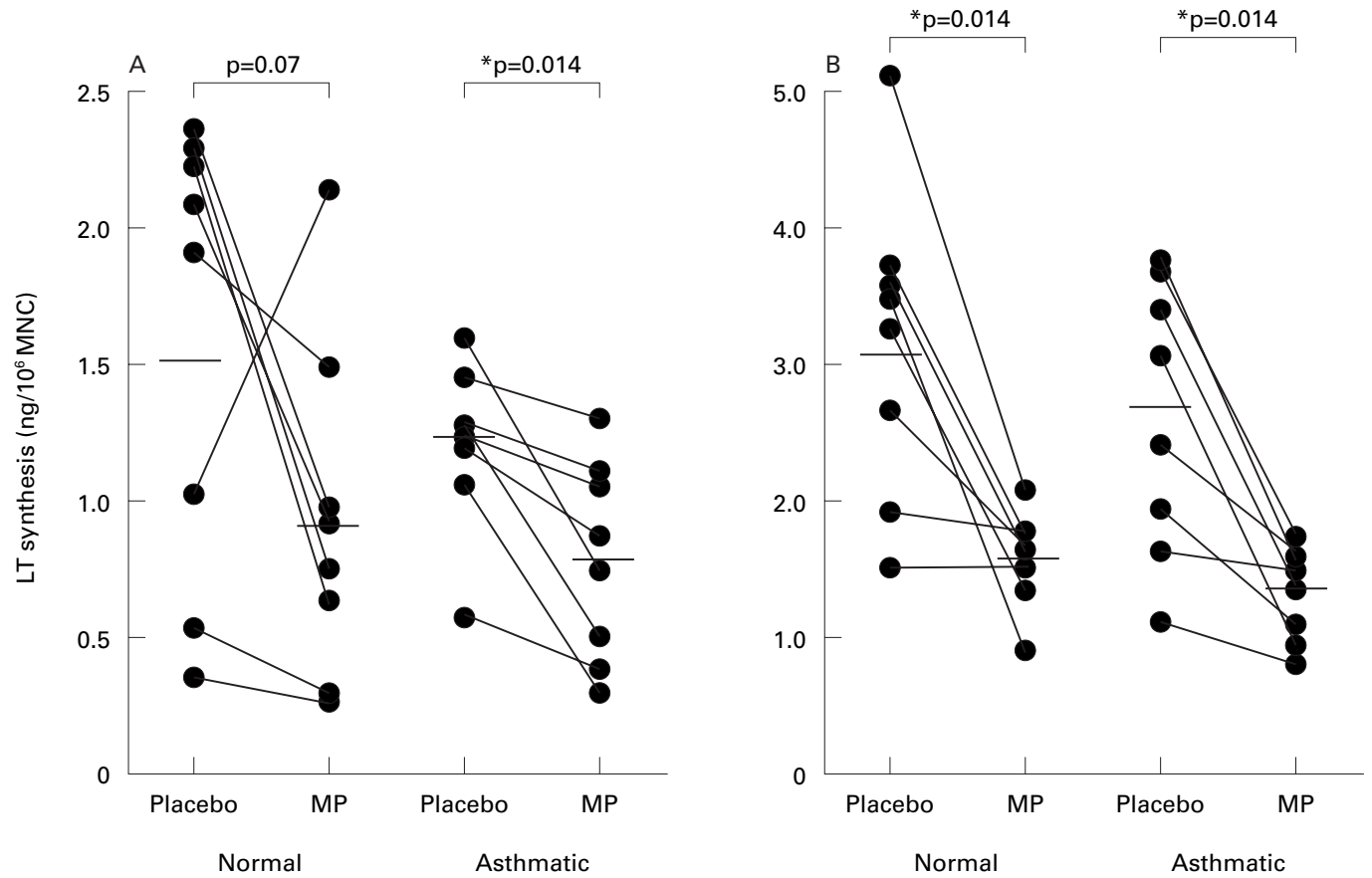

Figure 2 Ex vivo synthesis of $(A)$ LTC, and (B) LTB, by A23187 stimulated blood mononuclear cells (MNC) of normal subjects $(n=8)$ and asthmatic patients $(n=8)$ 4-6 hours after intravenous methylprednisolone (MP; 100 mg) and placebo. Horizontal bars indicate mean values. Synthesis of $L T C_{4}$ and $L T B_{4}$ by $M N C$ was not different between the subject groups after placebo. Methylprednisolone reduced synthesis of $L T C_{4}$ in the normal subjects $(p=0.07)$ and in asthmatic subjects $(p=0.014)$; if the one outlier is removed, the reduction in LTC after methylprednisolone also becomes significant in the normal group $(p=0.04, n=7)$. Methylprednisolone significantly reduced the synthesis of LTB in both subject groups $(p=0.014)$. 

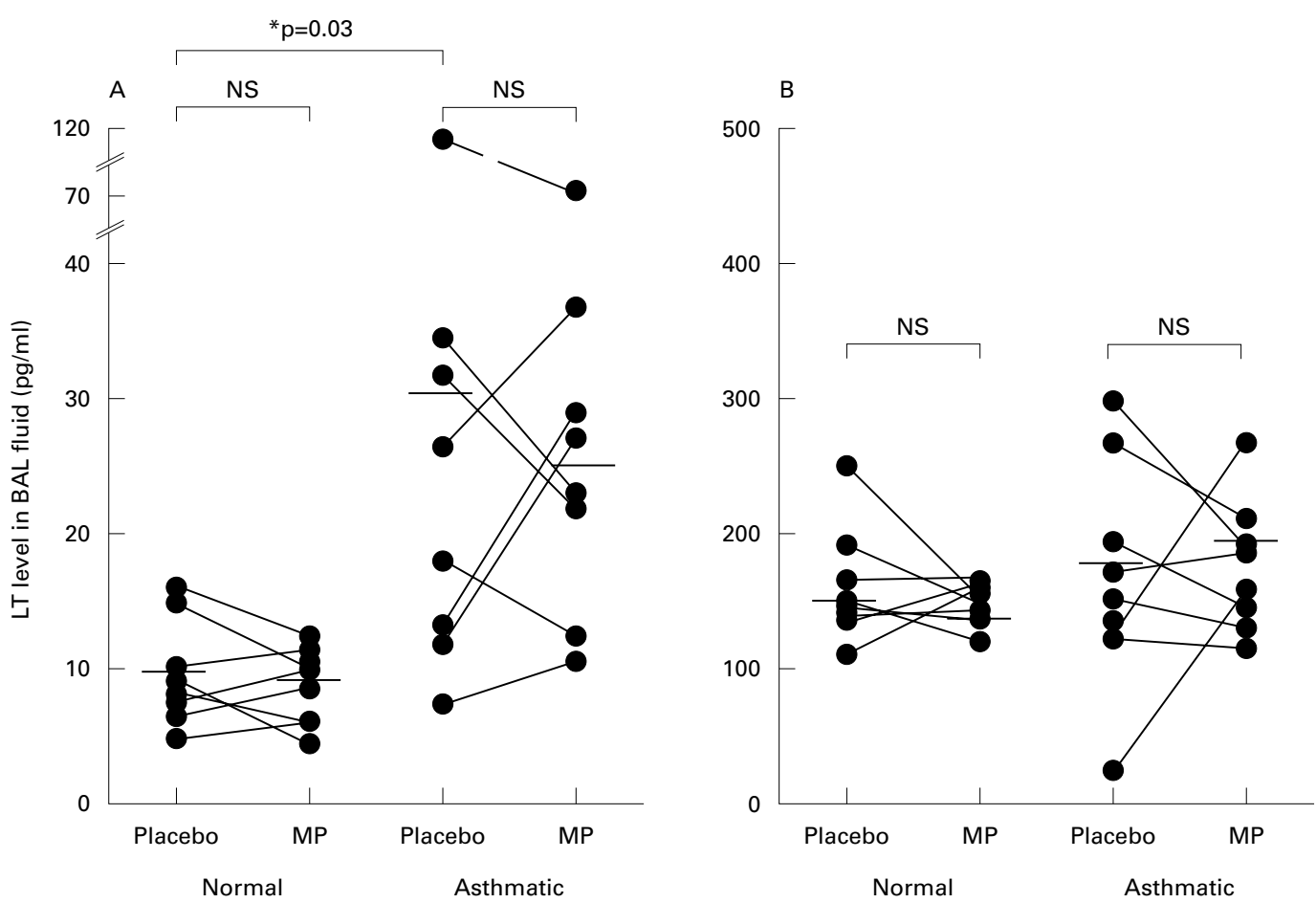

Figure 3 Levels of $(A) L T C$ and $(B) L T B$ in bronchoalveolar lavage $(B A L)$ fluid obtained from normal subjects $(n=$ $8)$ and asthmatic patients $(n=8)$ four hours after intravenous methylprednisolone (MP; $100 \mathrm{mg})$ and placebo. Horizontal bars indicate mean values ( $\mathrm{pg} / \mathrm{ml}$ ). BAL fluid levels of $L T C_{4}$ after placebo were significantly higher in the asthmatic patients than in normal subjects $(p=0.03)$ but basal LTB levels were not significantly different $(p=0.09)$. Methylprednisolone did not significantly alter BAL fluid levels of $L T C_{4}$ or $L T B_{4}$ in either subject group ( $\left.p>0.2\right)$.

cells after methylprednisolone $(\mathrm{p}=0.014 ;$ fig $2)$. The mean fall was $1.44 \mathrm{ng} / 10^{6}$ cells $(95 \%$ CI 0.72 to 2.15$)$.

EFFECT OF INTRAVENOUS METHYLPREDNISOLONE ON BAL FLUID LEVELS OF LEUKOTRIENES AND ON EX VIVO SYNTHESIS OF LEUKOTRIENES BY BAL CELLS

Assessment of the degree of dilution of ELF by instillation of sterile saline during BAL was performed by the inulin method as described elsewhere. ${ }^{18}$ The proportion of ELF in recovered BAL fluid was similar $(7-12 \%)$ in the normal and asthmatic groups, justifying direct comparisons of LT levels in BAL fluid between the groups. BAL fluid levels of LTC $_{4}$ after placebo were significantly higher in asthmatic patients $(30.6(11.7) \mathrm{pg} / \mathrm{ml}, \mathrm{n}=8)$ than in normal subjects $(9.7(1.0) \mathrm{pg} / \mathrm{ml}, \mathrm{n}=8, \mathrm{p}=0.027$, Mann-Whitney, 95\% CI for the difference 2.4 to $26.4 \mathrm{pg} / \mathrm{ml}$ ). However, methylprednisolone did not reduce BAL fluid levels of $\mathrm{LTC}_{4}$ either in the asthmatic patients $(25.1$ (6.9) $\mathrm{pg} / \mathrm{ml}$, $\mathrm{p}>0.2)$ or in the normal subjects $(9.0(0.7) \mathrm{pg} /$ $\mathrm{ml}, \mathrm{p}>0.3$ ) compared with placebo (fig 3 ).

BAL fluid levels of $\mathrm{LTB}_{4}$ after placebo were not significantly different in asthmatic patients (189 (29.5) pg/ml) and normal subjects (147 (15.0) $\mathrm{pg} / \mathrm{ml} ; \mathrm{p}=0.09$, Mann-Whitney). Methylprednisolone did not affect BAL fluid levels of $\mathrm{LTB}_{4}$ either in the asthmatic patients (199 (21.0) $\mathrm{pg} / \mathrm{ml}, \mathrm{p}>0.3$ ) or in the normal subjects (123 (19.0) pg/ml, p>0.2; fig 3 ).

BAL cells stimulated in vitro with calcium ionophore A23187 for 20 minutes generated $\mathrm{LTC}_{4}$ and $\mathrm{LTB}_{4}$. In normal subjects intravenous methylprednisolone did not alter A23187 stimulated synthesis of $\mathrm{LTC}_{4}(0.84$ (0.13) $\mathrm{ng} / 10^{6}$ cells) compared with placebo $\left(0.81(0.07) \mathrm{ng} / 10^{6}\right.$ cells $)$ nor the synthesis of $\mathrm{LTB}_{4}\left(9.31\right.$ (3.1) ng/ $10^{6}$ cells) compared with placebo $\left(6.7(2.0) \mathrm{ng} / 10^{6}\right.$ cells). In asthmatic patients ex vivo synthesis of $\mathrm{LTC}_{4}(0.62$ (0.01) ng/10 $0^{6}$ cells) and $\mathrm{LTB}_{4}\left(4.0(0.4) \mathrm{ng} / 10^{6}\right.$ cells) after placebo was similar to that observed in the normal subjects and was similarly unaffected by intravenous methylprednisolone $\left(0.62(0.02) \mathrm{ng} / 10^{6}\right.$ cells and $12.2(4.6) \mathrm{ng} / 10^{6}$ cells, respectively, $\mathrm{p}>0.05)$.

\section{Discussion}

The mechanisms by which systemic corticosteroids produce rapid clinical improvements in acute severe asthma are unclear. It is also unclear whether inhibition of leukotriene synthesis contributes to the anti-inflammatory effects of corticosteroids either in acute severe asthma or in chronic persistent asthma. Several multiple dose studies in asthmatic and normal subjects have failed to show an effect of corticosteroids on urinary $\mathrm{LTE}_{4}$ and BAL fluid $\mathrm{LTB}_{4}$ levels in persistent asthma. ${ }^{10-13}$ To explore the early effects of systemic corticosteroids we investigated the effects of a single dose of intravenous corticosteroid on LT synthesis at a time point (4-6 hours), much earlier than any previous single dose study but similar to the time course of clinical improvement seen in acute severe asthmatics following systemic corticosteroid therapy. ${ }^{15}{ }^{16}$ As well as in BAL cells and BAL fluid, LT synthesis was examined in blood polymorphonuclear leucocytes (PMNL) and mononuclear cells (MNC). Our results show for the first time that the enhanced capacity of blood PMNL to generate $\mathrm{LTC}_{4}$ in mild allergic asthmatic subjects is significantly reduced within six hours of intravenous administration of methylprednisolone. Furthermore, 
methylprednisolone markedly reduced ex vivo synthesis of both $\mathrm{LTC}_{4}$ and $\mathrm{LTB}_{4}$ in blood MNC from asthmatic patients and normal subjects. This rapid anti-inflammatory activity may contribute to the early therapeutic effects of systemic corticosteroids on lung function and airway inflammation in acute severe asthma.

The most profound changes seen following methylprednisolone administration were marked reductions in the ex vivo A23187 stimulated synthesis of LTs by blood leucocytes. Methylprednisolone suppressed the synthesis of the potent bronchoconstrictor and eosinophilotactic mediator $\mathrm{LTC}_{4}$ in blood PMNL of asthmatic patients $(p<0.03$; fig 1$)$. In normal subjects baseline synthesis of $\mathrm{LTC}_{4}$ by blood PMNL was only about half that in asthmatic PMNL ( $p=0.08$ ) and it was not significantly reduced by methylprednisolone. These $\mathrm{LTC}_{4}$ data are best explained by group differences in 5-LO pathway activity within the eosinophil subpopulation, as the capacity of human neutrophils to generate LTC $_{4}$ is negligible. $^{23}$ The data are unlikely to be explained by the tendency for eosinophil percentages within PMNL preparations to fall after methylprednisolone (table 1) as these falls did not reach statistical significance and occurred in both subject groups while the fall in LTC $_{4}$ synthesis was only seen in the asthmatic subjects. The trend for increased capacity of blood eosinophils from asthmatic subjects to synthesise LTC $_{4}$ agrees with significant results in previous studies ${ }^{19}{ }^{20}$ and may be due to in vivo priming by eosinophilotactic cytokines implicated in allergic inflammation such as interleukin (IL-) 3 and IL-5. ${ }^{22}$ The ability of methylprednisolone to reduce $\mathrm{LTC}_{4}$ synthesis in eosinophils in asthmatic subjects may prevent a vicious cycle of eosinophil migration and $\mathrm{LTC}_{4}$ synthesis. In contrast, the overwhelming source of $\mathrm{LTB}_{4}$ generated by PMNL preparations is the neutrophil ${ }^{23}$; the lack of effect of methylprednisolone on $\mathrm{LTB}_{4}$ synthesis in PMNL of both subject groups $(p>0.2)$ is consistent with the resistance of the LT pathway in blood neutrophils to suppression by corticosteroids in vitro. ${ }^{24}$ However, the relatively low statistical power of the study $(n=8)$ means that we cannot entirely exclude a small effect of methylprednisolone on the $\mathrm{LTB}_{4}$ pathway.

In blood MNC, even though there were no differences in baseline LT synthesis between the normal and asthmatic groups, synthesis of $\mathrm{LTC}_{4}$ and $\mathrm{LTB}_{4}$ was significantly reduced in both groups within six hours of intravenous methylprednisolone (fig 2). The primary source of both LTs in human MNC preparations is likely to be the monocyte. The reduced $\mathrm{LTB}_{4}$ and $\mathrm{LTC}_{4}$ synthesis cannot be due to corticosteroid induced alterations in the proportion of monocytes within the MNC preparations as the ratio of monocytes to lymphocytes remained the same after methylprednisolone in both subject groups (table 1). The dual inhibition of $\mathrm{LTB}_{4}$ and $\mathrm{LTC}_{4}$ synthesis suggests that methylprednisolone acts at a proximal site in the 5-LO pathway in MNC, not at the level of the termi- nal enzymes $\mathrm{LTA}_{4}$ hydrolase or $\mathrm{LTC}_{4}$ synthase. This is supported by the finding that abolition of ex vivo LT synthesis in blood leucocytes following treatment of asthmatics for more than one year with systemic deflazacort is related to reductions in $\mathrm{PLA}_{2}$ and 5-LO activity. ${ }^{14}$ Our data suggest that these changes are initiated in MNC within six hours of exposure to a single dose of a systemic corticosteroid.

Methylprednisolone concentrations in prelavage ELF four hours after intravenous injection were estimated by correcting mass spectrometry values in BAL fluid by an inulin dilution factor. ${ }^{18}$ The concentration of methylprednisolone achieved in ELF (approximately $0.2 \mu \mathrm{M}$ ) is sufficient to inhibit in vitro synthesis of $\mathrm{LTC}_{4}$ and $\mathrm{LTB}_{4}$ in rat alveolar macrophages by approximately $80 \% .{ }^{25}$ Despite this, in both subject groups intravenous methylprednisolone failed to reduce ex vivo synthesis of $\mathrm{LTB}_{4}$ or $\mathrm{LTC}_{4}$ by BAL cells (approximately 90\% macrophages) compared with placebo. This result contrasts with those of multiple dose corticosteroid studies which show reductions in spontaneous and zymosan stimulated synthesis of $\mathrm{LTB}_{4}$ ex vivo in macrophage-rich BAL cells from asthmatic and normal subjects. $^{1013}$ One explanation is that the number of subjects in this study $(\mathrm{n}=8)$ was too low to detect a reduction in LT synthesis in BAL cells. However, since significant reductions were observed in PMNL and MNC, it is more likely that the intravenous route of administration allowed more rapid access of methylprednisolone to the circulating leucocyte pool than to the cells in the airway lumen. Our data are also consistent with the relatively modest suppression of $\mathrm{LTB}_{4}$ synthesis observed in vitro in alveolar macrophages from normal and asthmatic subjects after culture with methylprednisolone $(1 \mu \mathrm{M})$ for 16 hours ${ }^{26}$ and with a study showing no inhibition of A23187 stimulated synthesis of $\mathrm{LTB}_{4}$ in alveolar macrophages of normal and nonnocturnal asthmatic subjects 13 hours after a single dose of prednisone. ${ }^{17}$ Together, these data suggest that in normal and mild nonnocturnal asthmatic subjects a single systemic dose of corticosteroid has no effect on 5-LO pathway activity in airway macrophages within 13 hours. The effects of corticosteroids on BAL cell synthesis in multiple dose studies may reflect subtle long term changes in macrophage phenotype or activation status within the airway. ${ }^{10}$

The lack of effect of methylprednisolone on LT synthesis in BAL cells is supported by the lack of change in $\mathrm{LTB}_{4}$ and $\mathrm{LTC}_{4}$ in BAL fluid (fig 3). In agreement with other workers, ${ }^{3}$ we found that, after placebo, levels of $\mathrm{LTC}_{4}$ were significantly higher in the BAL fluid of allergic asthmatic patients than in normal subjects. The basal elevation in BAL fluid $\mathrm{LTC}_{4}$ in the asthmatic subjects was more than threefold but it is possible that lack of statistical power in this study may have precluded the detection of a relatively modest effect of methylprednisolone on BAL fluid LT levels. Alternatively, the lack of effect of methylprednisolone may indicate that, in normal and mild stable asthmatic 
subjects, BAL fluid $\mathrm{LTC}_{4}$ levels reflect ongoing degranulation of mast cells rather than activation of infiltrating leucocytes such as eosinophils as in vitro studies show that overnight treatment of human lung mast cells with corticosteroids in vitro fails to inhibit $\mathrm{LTC}_{4}$ release. $^{27}$

Inhibition of ex vivo LT synthesis by intravenous methylprednisolone thus appears to be most evident in blood eosinophils and monocytes, although smaller effects on BAL cells and fluid cannot be excluded due to the relatively small number of subjects studied. We have recently linked deterioration in lung function in mild mono-allergic asthmatic subjects during the birch pollen season to specific increases in 5-LO pathway enzyme expression in bronchial biopsies which were entirely explained by influx of eosinophils and monocytes. ${ }^{28}$ The present data suggest that blood eosinophils and monocytes are early cellular targets of systemic steroids.

The mechanisms by which corticosteroids modulate LT synthesis in blood leucocytes are unclear. Corticosteroids are thought to modulate gene expression by interaction of the steroid receptor complex with glucocorticoid response elements (GRE) in gene promoters or by interaction with nuclear transcription factors such as $\mathrm{NF}-\kappa \mathrm{B} .{ }^{29}$ Genes regulated directly or indirectly by steroids include a range of pro-inflammatory cytokines, adhesion molecules, and enzymes. Corticosteroids may modulate LT synthesis by regulating expression of 5-LO pathway enzymes as the FLAP gene promoter contains a $\mathrm{GRE}^{30}$ while the 5-LO promoter has an $\mathrm{NF}-\kappa \mathrm{B}$ recognition sequence. $^{31}$ Our use of calcium ionophore A23187 as a stimulus rather than a receptor dependent stimulus such as zymosan allows the site of action of methylprednisolone to be localised to the 5-LO pathway itself and not to changes in cell surface receptor density, and the potency of A23187 maximises the sensitivity of the model. Paradoxical upregulation by corticosteroids of 5-LO and/or FLAP expression has been reported in human monocytes, neutrophils, and eosinophils ${ }^{32-35}$ although such changes do not necessarily alter cellular capacity for LT synthesis. ${ }^{33}{ }^{35}$ Inhibition of LT synthesis in alveolar macrophages by multiple dose glucocorticoid therapy is associated with induction of the $\mathrm{PLA}_{2}$ inhibitor lipocortin-1 but this appears not to occur in blood granulocytes or monocytes in vivo. ${ }^{36}$ Recent evidence suggests fluticasone inhibits $\mathrm{LTC}_{4}$ synthesis in human eosinophils in vitro by blocking translocation of $\mathrm{cPLA}_{2}$ to the nuclear envelope. ${ }^{37}$ Such a mechanism is consistent with dual inhibition of $\mathrm{LTB}_{4}$ and $\mathrm{LTC}_{4}$ synthesis reported in $\mathrm{MNC}$ in the present study and with suppression of prostanoid synthesis reported by others. ${ }^{33}$

Overall, the effects of corticosteroids on LT synthesis in vivo depend on the populations and activation status of leucocytes in the airway and other compartments, and on the balance between the induction of lipocortin expression, modulation of $\mathrm{PLA}_{2}$, 5-LO, and/or FLAP activity and expression, and changes in the density of membrane receptors for immunological stimuli. Our study provides useful insights into the net result of these conflicting factors within the first six hours of systemic steroid administration, showing that the most pronounced early effect is a reduction in the capacity of PMNL in asthmatic blood to generate $\mathrm{LTC}_{4}$, and in the capacity of blood monocytes from both patient groups to synthesise $\mathrm{LTC}_{4}$ and $\mathrm{LTB}_{4}$. These changes may contribute to early improvements in lung function and to the suppression of airway eosinophilic inflammation following systemic corticosteroid therapy in acute asthma.

This work was supported by the Upjohn Company and by the Frances \& Augustus Newman Foundation. The authors thank Dr A W Ford-Hutchinson (Merck-Frosst Canada) and Professor B Peskar (University of Graz, Austria) for generous gifts of leukotriene antisera.

1 Hay DWP, Torphy TJ, Undem BJ. Cysteinyl leukotrienes in asthma: old mediators up to new tricks. TIPS 1995;16:304-

2 Laitinen LA, Laitinen A, Haahtela T, et al. Leukotriene $\mathrm{E}_{4}$ and granulocytic infiltration into asthmatic airways. Lance 1993;341:989-90.

3 Wenzel SE, Larsen GL, Johnston K, et al. Elevated levels of leukotriene $\mathrm{C}_{4}$ in bronchoalveolar lavage fluid from atopic asthmatics after endobronchial allergen challenge. Am Rev asthmatics after endobronchia

Taylor GW, Taylor IK, Black PN, et al. Urinary leukotriene $\mathrm{E}_{4}$ after allergen challenge and in acute asthma and allergic $\mathrm{E}_{4}$ after allergen challenge and
rhinitis. Lancet $1989 ; \mathrm{i}: 584-8$.

5 Holgate ST, Bradding P, Sampson AP. Leukotriene antagonists and synthesis inhibitors: new directions in asthma therapy. $\mathcal{F}$ Allergy Clin Immunol 1996;98:1-13.

6 Leff AR, Busse WW, Pearlman D, et al. Montelukast, a leukotriene receptor antagonist, for the treatment of mild asthma and exercise-induced bronchoconstriction. $N$ Engl f Med 1998;339:147-52.

7 Sampson SE, Costello JF, Sampson AP. The effect of inhaled leukotriene $\mathrm{B}_{4}$ in normal and in asthmatic subjects. Am f Respir Crit Care Med 1997;155:1789-92.

8 Christie PE, Barnes NC. Leukotriene $\mathrm{B}_{4}$ and asthma. Thorax 1996;51:1171-3.

9 Peers SH, Flower RJ. The role of lipocortin in corticosteroid actions. Am Rev Respir Dis 1990;141:S18-21.

10 Sebaldt RJ, Sheller JR, Oates JA, et al. Inhibition of eicosanoid synthesis by glucocorticoids. Proc Natl Acad Sci USA 1990;87:6974-8

11 Manso G, Baker AJ, Taylor IK, et al. In vivo and in vitro effects of glucocorticoids on arachidonic acid metabolism and monocyte function in nonasthmatic humans. Eu Respir F 1992; 5:712-6.

12 O'Shaughnessy KM, Wellings R, Gillies B, et al. Differential effects of fluticasone propionate on allergen-evoked bronchoconstriction and increased urinary leukotriene $\mathrm{E}_{4}$ excretion. Am Rev Respir Dis 1993;147:1472-6.

13 Dworski R, Fitzgerald GA, Oates JA, et al. Effect of oral prednisone on airway inflammatory mediators in atopic prednisone on airway inflammatory mediators in

14 Vachier I, Chavis C, Godard P, et al. Effect of non-inhaled glucocorticoids on neutrophils and monocytes eicosanoid production in asthmatic patients. Eur Respir F 1995;8:187s.

15 Storr J, Barrell E, Barry W, et al. Effect of a single oral dose of prednisolone in acute childhood asthma. Lancet 1987; 879-82.

16 Littenberg B, Gluck EH. A controlled trial of methylprednisolone in the emergency treatment of acute asthma. $N$ Engl f Med 1986;314:150-2.

17 Wenzel SE, Trudeau JB, Westcott JW, et al. Single oral dose of prednisone decreases leukotriene $\mathrm{B}_{4}$ production by lveolar macrophages fro alveolar macrophages from paticnis with nocturnal asthm 作

18 Restrick LJ, Sampson AP, Piper PJ, et al. Inulin as a marker of dilution of bronchoalveolar lavage in asthmatic and normal subjects. Am F Respir Crit Care Med 1995;151:1211-7.

19 Sampson AP, Thomas RU, Costello JF, et al. Enhanced leukotriene synthesis in leukocytes of atopic and asthmatic subjects. Br f Clin Pharmacol 1992;33:423-30.

20 Restrick LJ, Sampson AP, Piper PJ, et al. Reduction in leukotriene $\mathrm{B}_{4}$ generation by bronchoalveolar lavage cells in asthma. Thorax 1995;50:67-73.

21 Bruijnzeel PL, Virchow JC, Rihs S, et al. Lack of increased numbers of low-density eosinophils in the circulation of asthmatic individuals. Clin Exp Allergy 1993;23:261-9.

22 Takafuji S, Bischoff SC, De Weck AL, et al. IL-3 and IL-5 prime normal human eosinophils to produce LTC $_{4}$ in
response to soluble agonists. F Immunol 1991;147:3855-61.

23 Weller PF, Lee CW, Foster DW, et al. Generation and metabolism of 5-lipoxygenase pathway leukotrienes by human eosinophils: predominant production of leukotriene $\mathrm{C}_{4}$. Proc Natl Acad Sci USA 1983;80:7626-30 
24 Schleimer RP, Freeland HS, Peters SP, et al. An assessment of the effects of glucocorticoids on degranulation, chemotaxis, binding to vascular endothelium and formation of leukotriene $\mathrm{B}_{4}$ by purified human neutrophils. F Pharmacol Exp Ther 1989;250:598-605.

25 Peters-Golden M, Thebert P. Inhibition by methylprednisolone of zymosan-induced leukotriene synthesis in alveolar macrophages. Am Rev Respir Dis 1987;135:1020-6.

26 Balter MS, Eschenbacher WL, Peters-Golden M. Arachidonic acid metabolism in cultured alveolar macrophages from normal, atopic, and asthmatic subjects. Am Rev Respir Dis 1988;138:1134-42.

27 Peters SP, Naclerio RM, Schleimer RP, et al. The pharmacologic control of mediator release from human basophils and mast cells. Respiration 1986;50(Suppl 2):116-22.

28 Seymour ML, Aberg D, Riise G, et al. Seasonal allergen exposure increases expression of leukotriene pathway enzymes and induces eosinophil influx in bronchial mucosa of atopic asthmatics. F Allergy Clin Immunol 1998;101:711 (abstract).

29 Barnes PJ, Adcock I. Anti-inflammatory actions of steroids: molecular mechanisms. TIPS 1993;14:436-41.

30 Kennedy BP, Diehl RE, Boie Y, et al. Gene characterization and promoter analysis of human 5-lipoxygenase-activating protein (FLAP). F Biol Chem 1991;266:8511-6.

31 Hoshiko S, Radmark O, Samuelsson B. Characterization of the human 5-lipoxygenase promoter. Proc Natl Acad Sci USA 1990;87:9073-7.
32 Goppelt-Struebe M, Schaefer D, Habenicht AJR. Differential regulation of cyclooxygenase-2 and 5-lipoxygenaseactivating protein (FLAP) expression by glucocorticoids in monocytic cells. Br f Pharmacol 1997;122:619-24.

33 Pouliot M, McDonald PP, Borgeat P, et al. Granulocyte/ macrophage colony-stimulating factor stimulates the expression of the 5-lipoxygenase-activating protein (FLAP) in human neutrophils. $\mathcal{F}$ Exp Med 1994;179 1225-32.

34 Riddick CA, Ring WL, Baker JR, et al. Dexamethasone increases expression of 5-lipoxygenase and its activating protein in human monocytes and THP-1 cells. Eur $\mathcal{f}$ Biochem 1997;246:112-8.

35 Cowburn AS, Holgate ST, Sampson AP. IL-5 increases expression of 5-lipoxygenase-activating protein and translocates 5-lipoxygenase to the nucleus in human blood eosinophils. F Immunol 1999;163:456-65.

36 De Caterina R, Sicari R, Giannessi D, et al. Macrophagespecific eicosanoid synthesis inhibition and lipocortin-1 induction by glucocorticoids. F Appl Physiol 1993;75: induction

37 Sano A, Munoz NM, Sano H, et al. Inhibition of cPLA translocation and leukotriene $\mathrm{C}_{4}$ secretion by fluticasone propionate in exogenously activated human eosinophils. Am f Respir Crit Care Med 1999;159:1903-9. 